\title{
Office for
}

\section{Statistical Bulletin}

\section{Consumer Price Indices August 2011}

\section{Coverage: UK}

\section{Date: 13 September 2011}

Geographical Area: UK and GB

Theme: Economy

\section{Consumer Price Indices}

- CPI annual inflation stands at 4.5 per cent in August 2011

- RPI annual inflation stands at 5.2 per cent in August 2011

\section{The headlines for the August 2011 consumer prices index (CPI) are:}

- CPI annual inflation stands at 4.5 per cent, up from 4.4 per cent in July

- The main upward pressures to annual inflation came from clothing, fuels \& lubricants, furniture \& household goods and domestic heating

- The main downward pressure to annual inflation came from transport services, particularly passenger transport by air, sea and rail. There was also a downward pressure from recreation $\&$ culture, particularly from games, toys \& hobbies and, to a lesser extent, recording media and data processing equipment

Annual inflation as recorded by the retail prices index (RPI) stands at 5.2 per cent in August, up from 5.0 per cent in July. 
CPI: Percentage change over 12 months

\section{CPI: Percentage changes over 12 months}

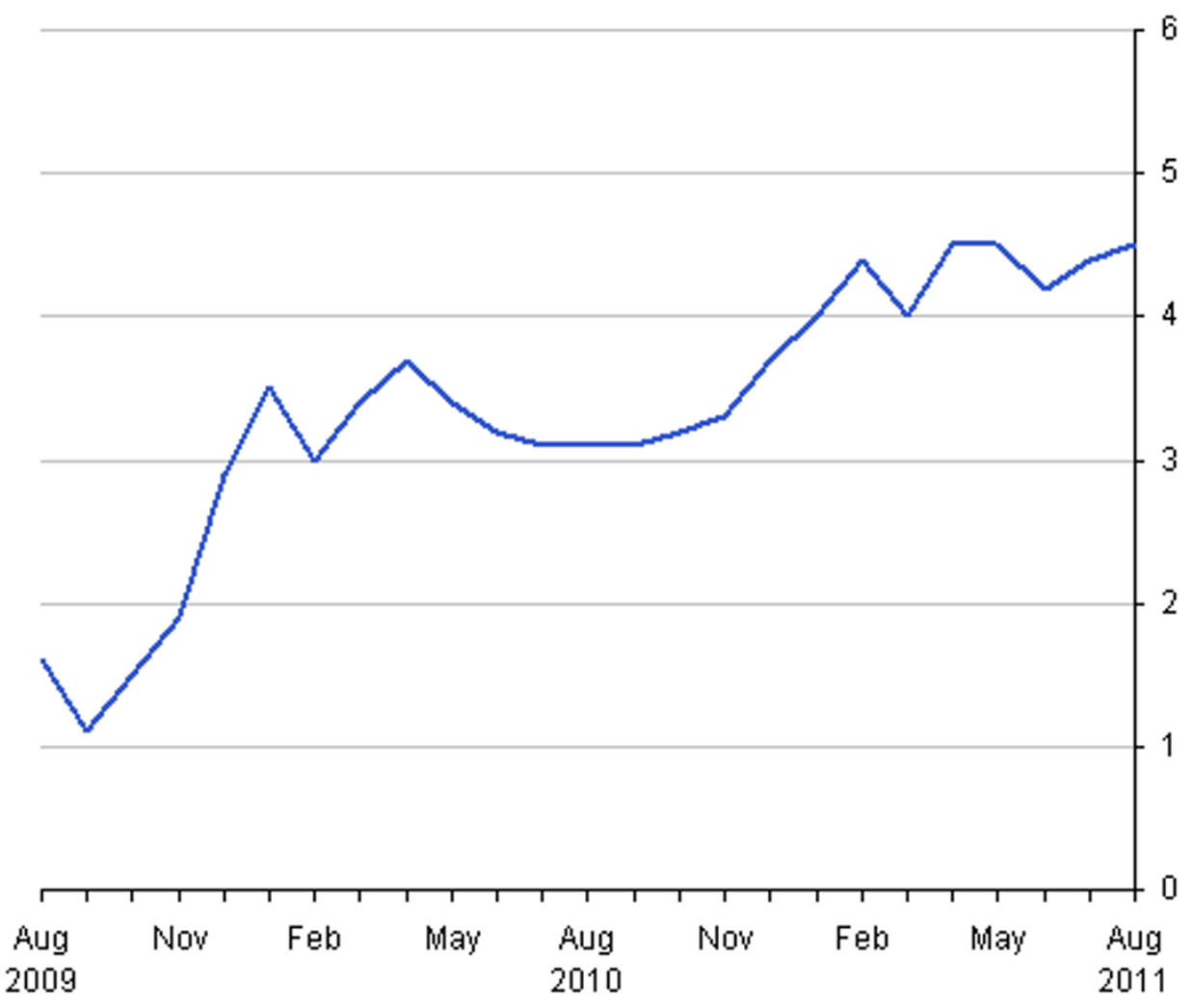

Download chart

XLS XLS format

$(22.5 \mathrm{~Kb})$ 
Consumer Prices Index (CPI)

United Kingdom

\begin{tabular}{|c|c|c|c|c|}
\hline & & $\begin{array}{r}\text { Index }^{1}(U K, 2005 \\
=100)\end{array}$ & $\begin{array}{r}\% \text { change over } 1 \\
\text { month }\end{array}$ & $\begin{array}{r}\% \text { change over } \\
12 \text { months }\end{array}$ \\
\hline \multirow[t]{5}{*}{2010} & Aug & 114.9 & 0.5 & 3.1 \\
\hline & Sep & 114.9 & 0.0 & 3.1 \\
\hline & Oct & 115.2 & 0.3 & 3.2 \\
\hline & Nov & 115.6 & 0.4 & 3.3 \\
\hline & Dec & 116.8 & 1.0 & 3.7 \\
\hline \multirow[t]{8}{*}{2011} & Jan & 116.9 & 0.1 & 4.0 \\
\hline & Feb & 117.8 & 0.7 & 4.4 \\
\hline & Mar & 118.1 & 0.3 & 4.0 \\
\hline & Apr & 119.3 & 1.0 & 4.5 \\
\hline & May & 119.5 & 0.2 & 4.5 \\
\hline & Jun & 119.4 & -0.1 & 4.2 \\
\hline & Jul & 119.4 & 0.0 & 4.4 \\
\hline & Aug & 120.1 & 0.6 & 4.5 \\
\hline
\end{tabular}

Table notes:

1. All items Consumer Prices Index

\section{Download table}

XLS XLS format

(15 Kb) 


\section{Briefing on the CPI monthly movement between July and August}

\section{1-month change to August}

\section{$\%$ change}

Food \& non-alcoholic beverages

Alcohol \& tobacco $-0.6$

Clothing \& footwear

Housing \& household services

Furniture \& household goods

Health

Transport

Communication

Recreation \& culture

Education

Restaurants \& hotels

Miscellaneous goods \& service

\section{Download table}

XLS XLS format

$(22.5 \mathrm{~Kb})$ 


\section{Contributions to 1-month percentage change}

(total CPI 0.6 per cent)

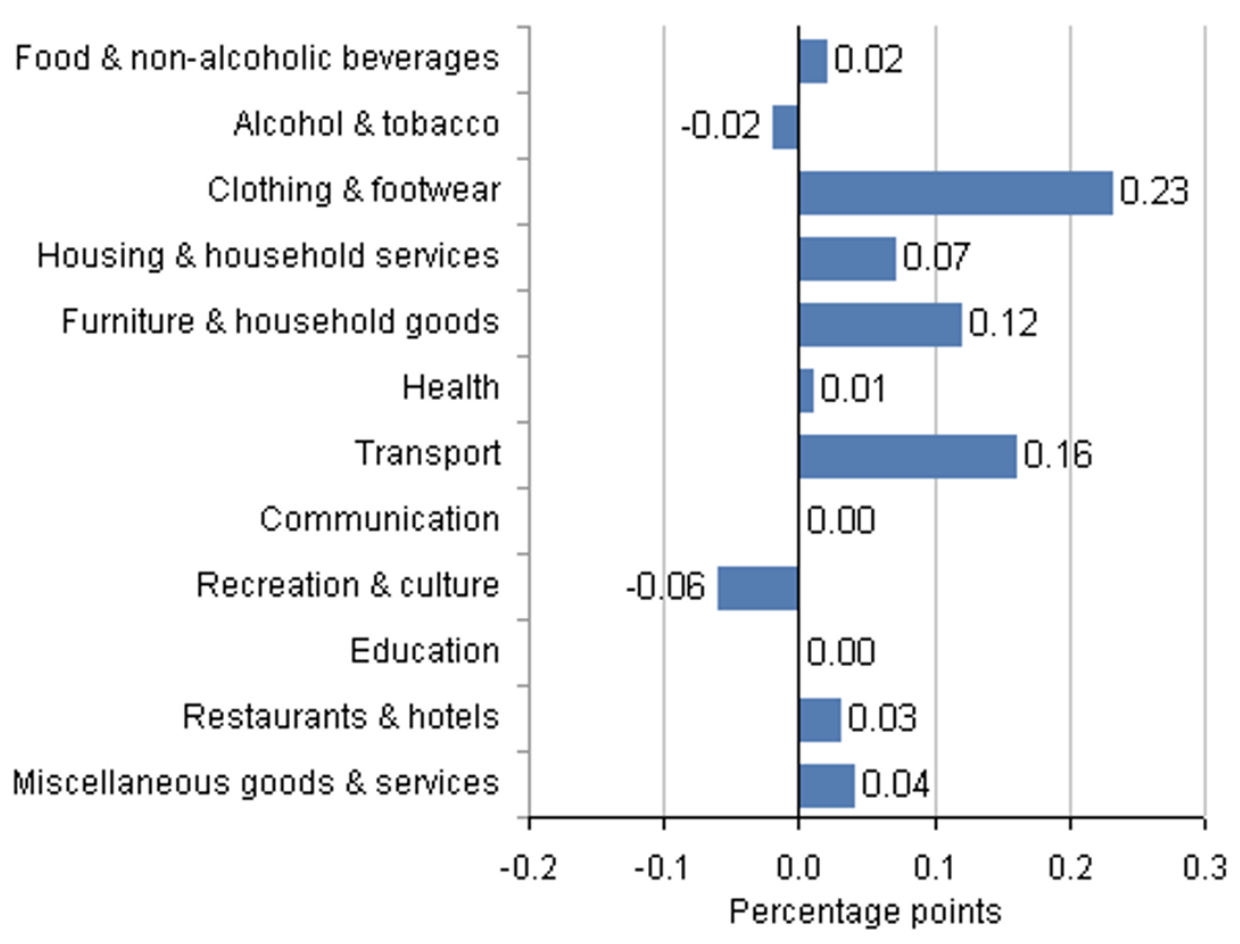

Notes:

1. Individual contributions may not sum to the total due to rounding.

\section{Download chart}

\section{XLS XLS format}

$(23.5 \mathrm{~Kb})$

The CPI rose by 0.6 per cent between July and August this year compared with a rise of 0.5 per cent a year ago. These 1-month changes are at the top end of the range for a July to August period and the 0.6 per cent rise this year equals the previous record July to August movement observed in 2008. Between 1996 and 2009, the 1-month change between July and August has varied between no change and an increase of 0.6 per cent.

The most significant upward contributions to the 1-month change in the CPI between July and August 2011 came from:

- clothing \& footwear: prices, overall, rose by 3.7 per cent, the largest rise for a July to August period on record. The largest upward effect came from women's outerwear, where prices rose at the start of the Autumn season

- transport: by far the largest upward effect came from air transport where fares rose by 11.2 per cent 
- furniture, household equipment \& maintenance: prices overall rose by 2.0 per cent, a record rise for a July to August period. The largest upward effects came from furniture \& furnishings and non-durable household goods where prices rose by 2.3 per cent and 4.9 per cent respectively

- housing \& household services: the largest upward effects came from gas and electricity where there were price rises on some tariffs

The most significant downward contribution to the 1-month change in the CPI between July and August 2011 came from:

- recreation \& culture: prices, overall, fell by 0.4 per cent, the first fall for a July to August period since 2005. The most significant downward effect came from games, toys \& hobbies, particularly computer games and games consoles

\section{Briefing on the change to the CPI 12-month rate in August 2011}

\section{Contributions to the change in the 12-month rate}

(total CPI 0.1 percentage points)

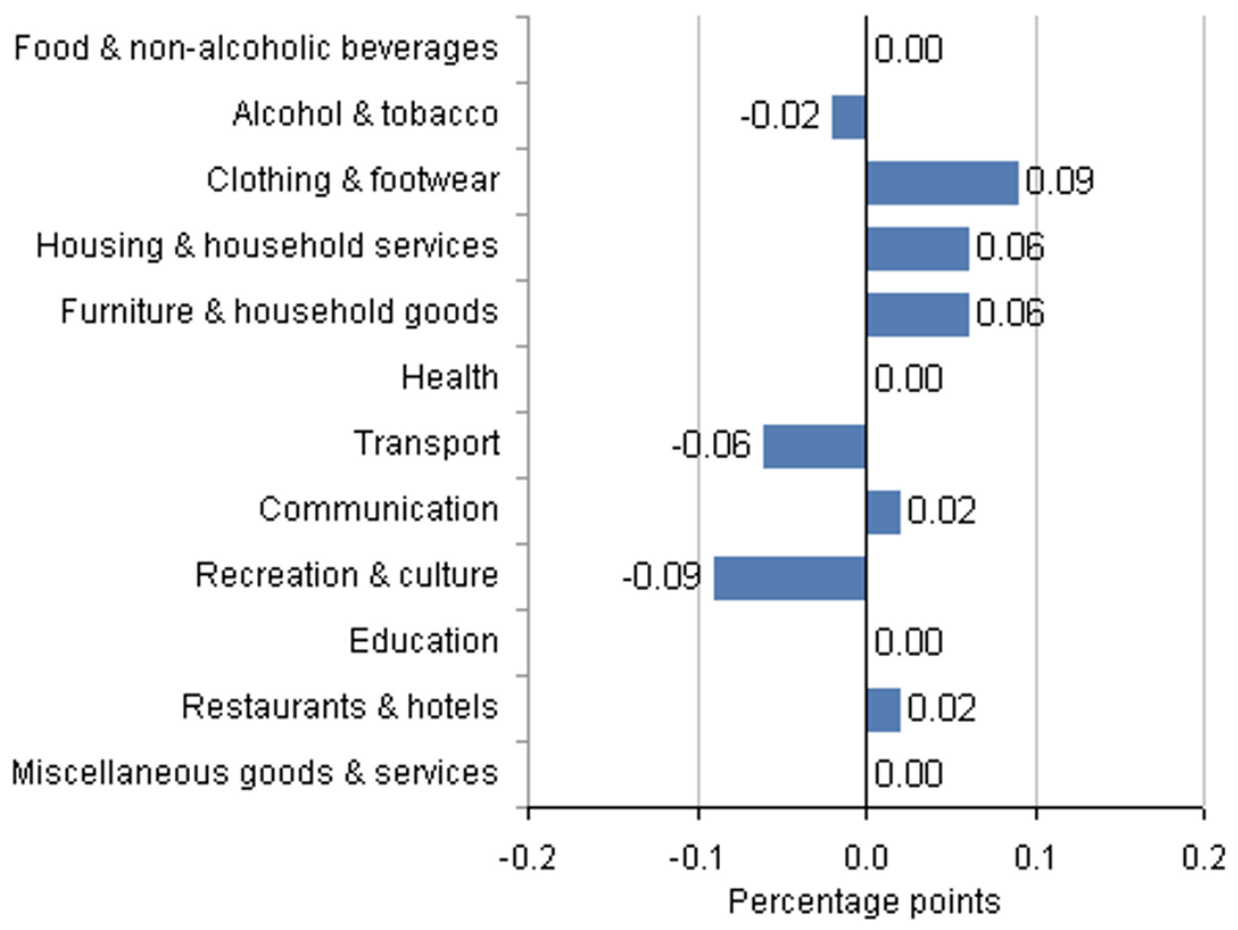

Notes:

1. Compared with the 12-month rate in July 2011.

2. Individual contributions may not sum to the total due to rounding. 


\section{Download chart}

XLS XLS format

$(22.5 \mathrm{~Kb})$

The change in the CPI 12-month rate is calculated by comparing the price changes between the latest two months and the same two months a year ago. This year the CPI rose by 0.6 per cent between July and August compared with a rise of 0.5 per cent between the same two months a year ago. The 1-month movement was therefore 0.1 percentage points higher this year and this led to the CPI 12-month rate increasing from 4.4 per cent in July to 4.5 per cent in August 2011.

The most significant upward contributions to the change in the CPI 12-month rate between July and August 2011 came from:

- clothing \& footwear: prices, overall, rose by 3.7 per cent between July and August this year compared with a rise of 2.8 per cent between the same two months a year ago. The largest upward effects came from women's outerwear and, to a lesser extent, men's outerwear

- housing \& household services: the largest upward effects came from gas and electricity where average bills rose this year but were unchanged a year ago

- furniture, household equipment \& maintenance: prices, overall, rose by 2.0 per cent between July and August this year compared with a rise of 1.0 per cent a year ago. The main upward effects came from non-durable household goods, where prices of cleaning products rose by more than a year ago, and carpets \& other floor coverings, where carpet prices also rose by more than a year ago

- communication: a small upward effect was driven by telephone equipment \& services where prices rose by 0.1 per cent between July and August this year but fell by 0.8 per cent a year ago. The largest upward contribution came from mobile phone charges where prices fell by less than a year ago

- restaurants \& hotels: prices, overall, rose by 0.2 per cent between July and August this year compared with 0.1 per cent a year ago

The most significant downward contributions to the change in the CPI 12-month rate between July and August 2011 came from:

- recreation \& culture: prices, overall, fell by 0.4 per cent between July and August this year compared with a rise of 0.2 per cent between the same two months a year ago. There was a large downward effect from games, toys \& hobbies, particularly computer games and games consoles. Other smaller downward effects came from recording media and data processing equipment. These were partially offset by a small upward effect from photographic equipment where digital cameras rose in price this year but fell a year ago 
- transport: prices, overall, rose by 1.0 per cent between July and August this year compared with a rise of 1.3 per cent a year ago. The downward effect came from transport services, particularly passenger transport by air and, to a lesser extent, passenger transport by sea and by rail. Air fares rose by 11.2 per cent on the month, less than the 16.1 per cent record for a July to August movement a year ago. The downward effect is partially offset by an upward contribution from fuels \& lubricants, particularly petrol and, to a lesser extent, diesel. The price of petrol rose by 0.9 pence per litre between July and August this year, to stand at $£ 1.35$ per litre, compared with a fall of 1.2 pence a year ago. The price of diesel rose by 1.0 pence per litre this year compared with a fall of 1.2 pence a year ago. There was also a small upward effect from second-hand cars where prices fell by less than a year ago

- alcoholic beverages \& tobacco: prices, overall, fell by 0.6 per cent this year, a record fall for a July to August period, compared with a fall of 0.1 per cent a year ago. The effect was driven by spirits where prices fell by 6.4 per cent this year, due to supermarket-led sales of whisky and vodka, compared with a 0.2 per cent fall a year ago

\section{Briefing on the CPI 12-month rate to August 2011}

\section{2-month rate to August}

$\%$ change

$\begin{array}{ll}\text { Food \& non-alcoholic beverages } & 6.2\end{array}$

$\begin{array}{lr}\text { Alcohol \& tobacco } & 9.8\end{array}$

$\begin{array}{lr}\text { Clothing \& footwear } & 4.0\end{array}$

$\begin{array}{ll}\text { Housing \& household services } & 5.1\end{array}$

$\begin{array}{ll}\text { Furniture \& household goods } & 5.8\end{array}$

$\begin{array}{lr}\text { Health } & 3.4\end{array}$

$\begin{array}{ll}\text { Transport } & 7.4\end{array}$

$\begin{array}{ll}\text { Communication } & 3.4\end{array}$

$\begin{array}{lr}\text { Recreation \& culture } & -0.8\end{array}$

$\begin{array}{ll}\text { Education } & 5.3\end{array}$

$\begin{array}{lr}\text { Restaurants \& hotels } & 4.6\end{array}$

$\begin{array}{lr}\text { Miscellaneous goods \& services } & 2.8\end{array}$

$\begin{array}{ll}\text { CPI All ltems } & 4.5\end{array}$

\section{Download table}

XLS XLS format

$(23.5 \mathrm{~Kb})$ 


\section{Contributions to 12-month rate}

(total CPI 4.5 per cent)

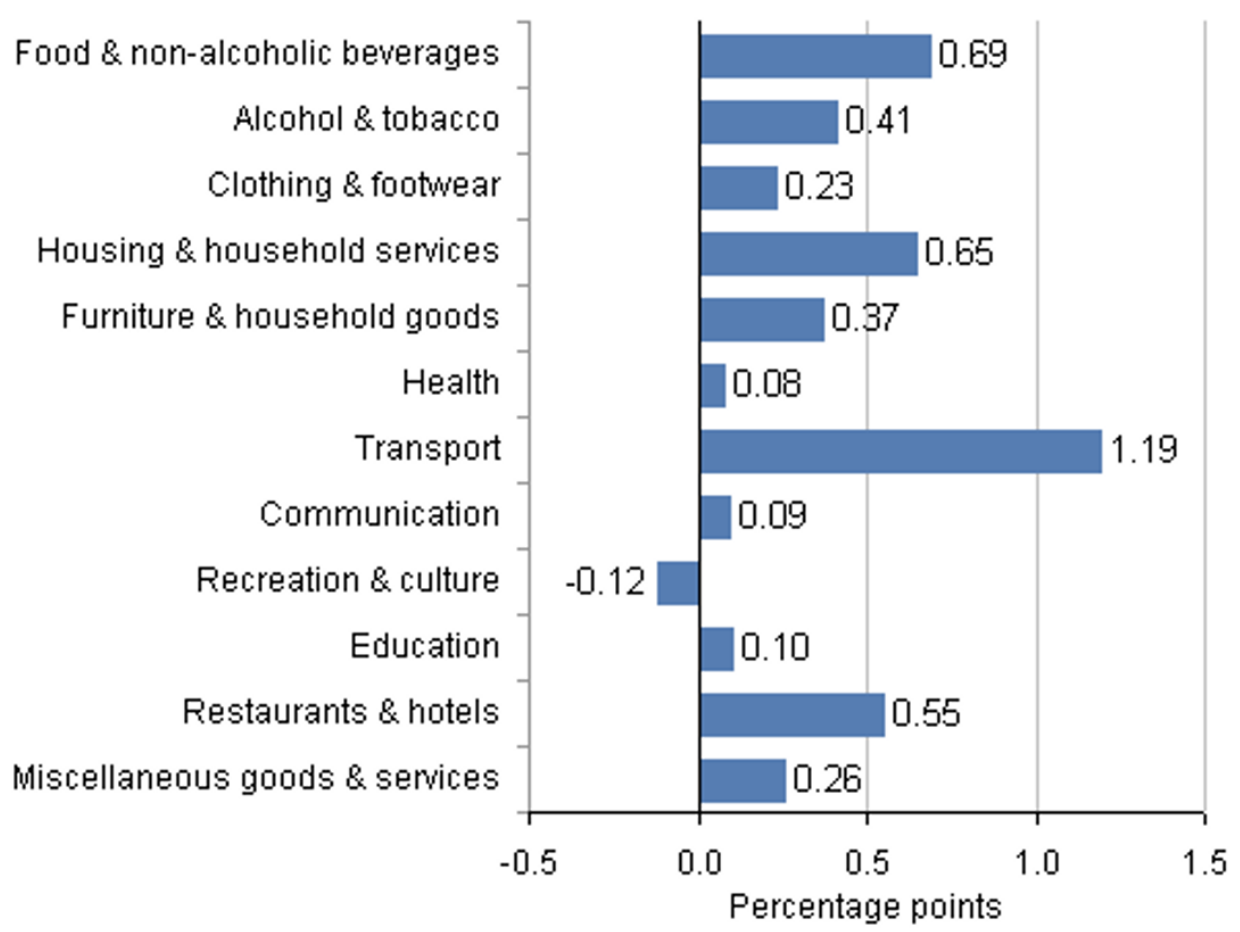

Notes:

1. Individual contributions may not sum to the total due to rounding.

\section{Download chart}

XLS XLS format

$(14 \mathrm{~Kb})$

The most significant upward contributions to the CPI 12-month rate to August 2011 came from:

- transport which contributed 1.2 percentage points. The largest effects came from fuels \& lubricants where prices, overall, rose by 17.0 per cent over the 12 months to August and air transport where fares rose by 7.7 per cent over the same period

- food and non-alcoholic beverages which contributed 0.7 percentage points with prices, overall, rising by 6.2 per cent over the year. The largest upward contributions came from meat where prices rose by 7.1 per cent over the 12 months to August, bread \& cereals where there was also a 7.1 per cent rise, mineral waters, soft drinks \& juices with a 9.4 per cent rise, and sugar, jam, syrups, chocolate $\&$ confectionery where prices rose by 7.6 per cent 
- housing and household services which also contributed 0.7 percentage points with upward effects from a range of categories, the largest being domestic heating costs and rents

- restaurants and hotels which contributed 0.6 percentage points. Here, restaurant \& cafe prices, overall, rose by 5.0 per cent over the year

\section{Other measures of CPI inflation}

\section{Percentage changes over 12 months}

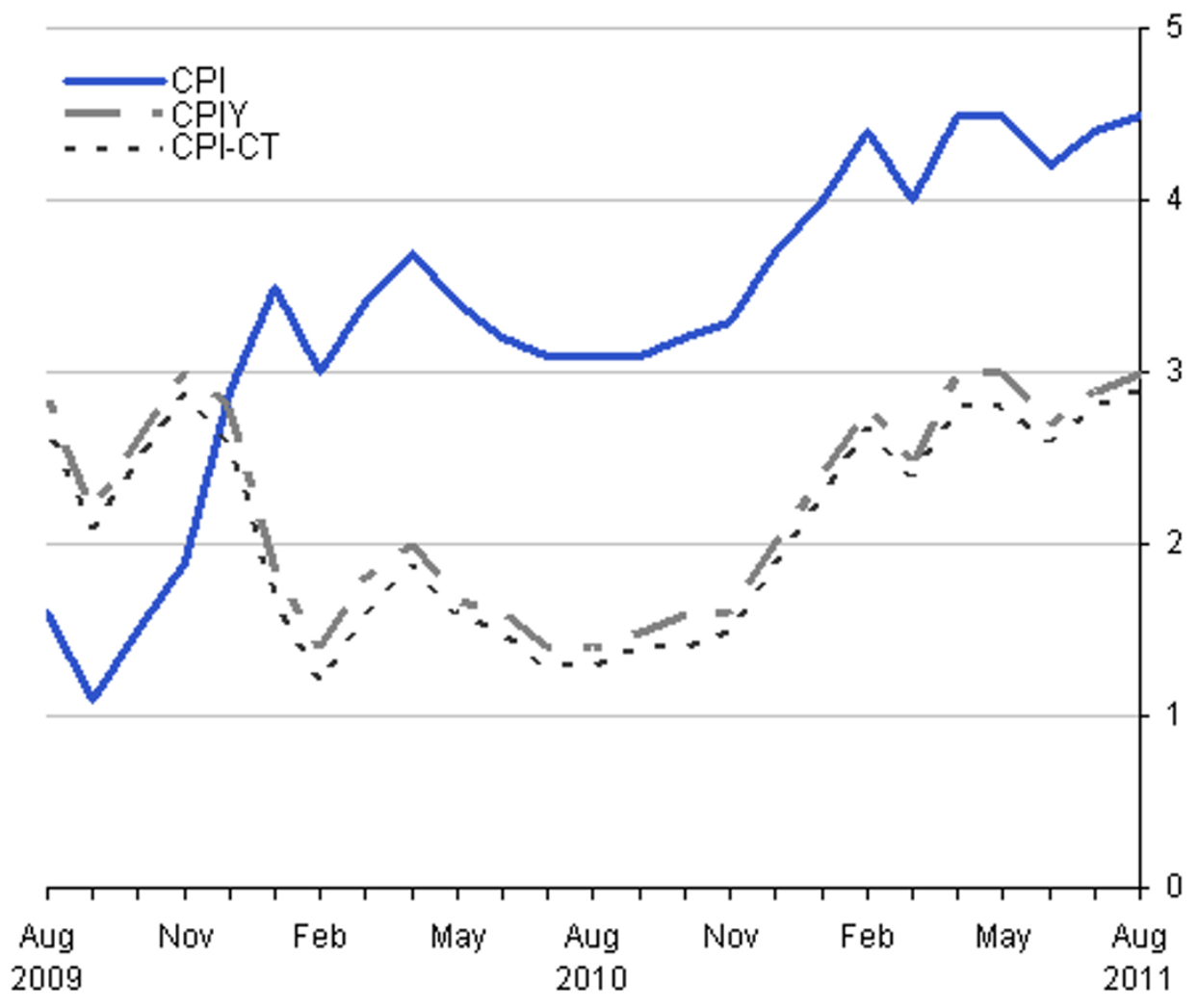

\section{Download chart}

\section{XLS XLS format}

$(14.5 \mathrm{~Kb})$

\section{Consumer Prices Index excluding indirect taxes (CPIY)}

The CPIY is the same as the all items CPI except that it excludes price changes which are directly due to changes in indirect taxation (such as VAT).

In the year to August, the CPIY rose by 3.0 per cent, up from 2.9 per cent in July. The CPIY and CPI 12-month rates have therefore both increased by 0.1 percentage points between July and August. This is because there were no changes to indirect taxation that impacted on the CPI between July and August. 


\section{Consumer Prices Index at constant tax rates (CPI-CT)}

The CPI-CT is the same as the CPI except that tax rates are kept constant at the rates they were in the base period (currently January 2011).

In the year to August, CPI-CT rose by 2.9 per cent, up from 2.8 per cent in July. The CPI-CT and CPI 12-month rates have therefore both increased by 0.1 percentage points between July and August. This is because there were no changes to indirect taxation that impacted on the CPI between July and August.

\section{RPI compared with CPI}

\section{RPI compared with CPI}

Percentage changes over 12 months

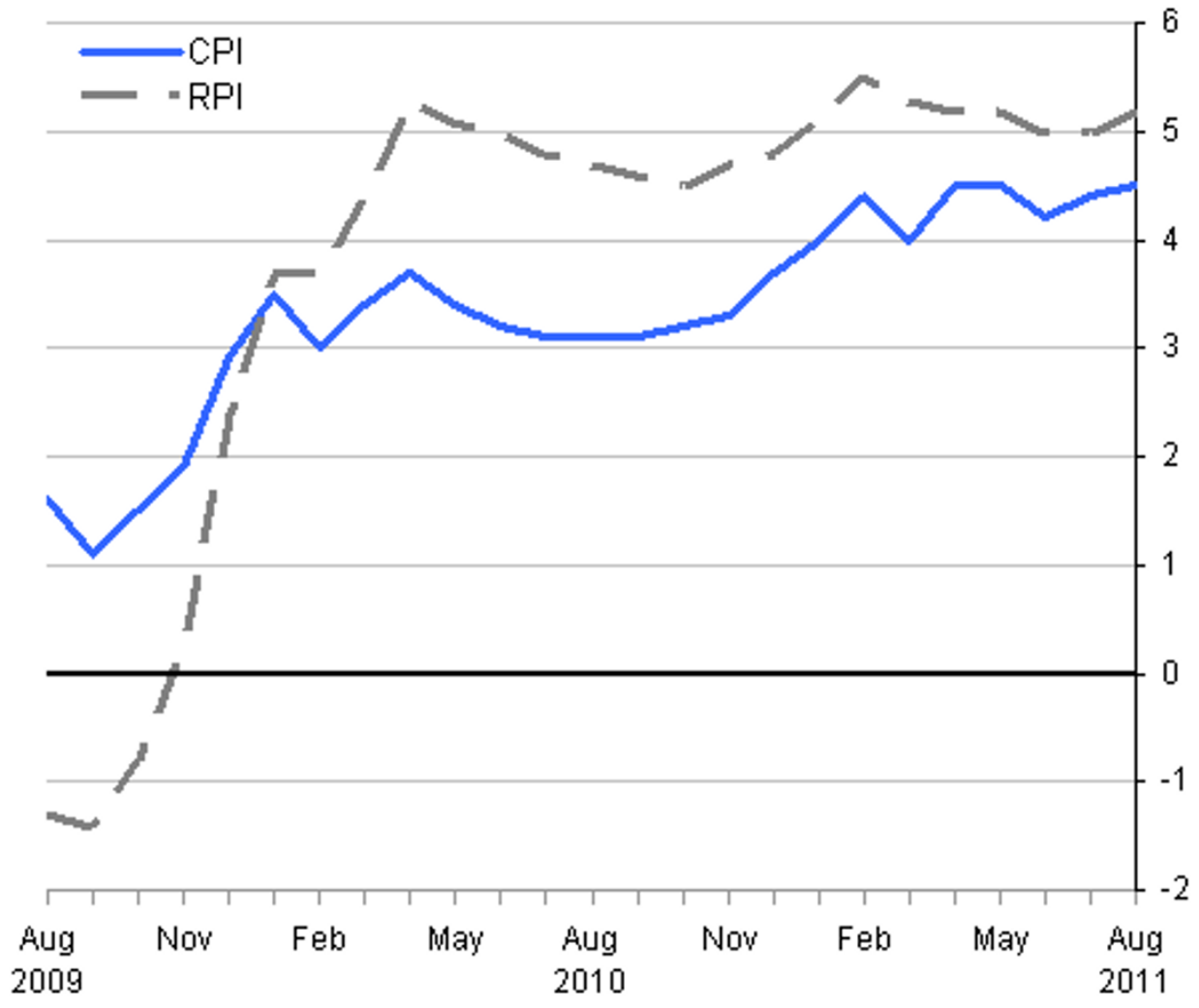

\section{Download chart}

\section{XLS XLS format}

$(24 \mathrm{~Kb})$ 


\section{All items Retail Prices Index (RPI)}

In the year to August the all items RPI rose by 5.2 per cent, up from 5.0 per cent in July. The RPI 12-month rate between July and August has therefore increased by 0.2 percentage points compared with a rise of 0.1 percentage points in the CPI 12-month rate between the same two months.

The larger rise in the RPI 12-month rate is mainly due to:

- air transport: has a much lower weight in the RPI than the CPI so the downward effect from this component had a smaller impact on the RPI

- games, toys and hobbies: have lower weights in the RPI than the CPI so the downward effect from these components had a smaller impact on the RPI

- sea transport: has a much lower weight in the RPI than the CPI so the downward effect from this component had a smaller impact on the RPI

\section{Other measures of RPI inflation}

\section{Percentage changes over 12 months}

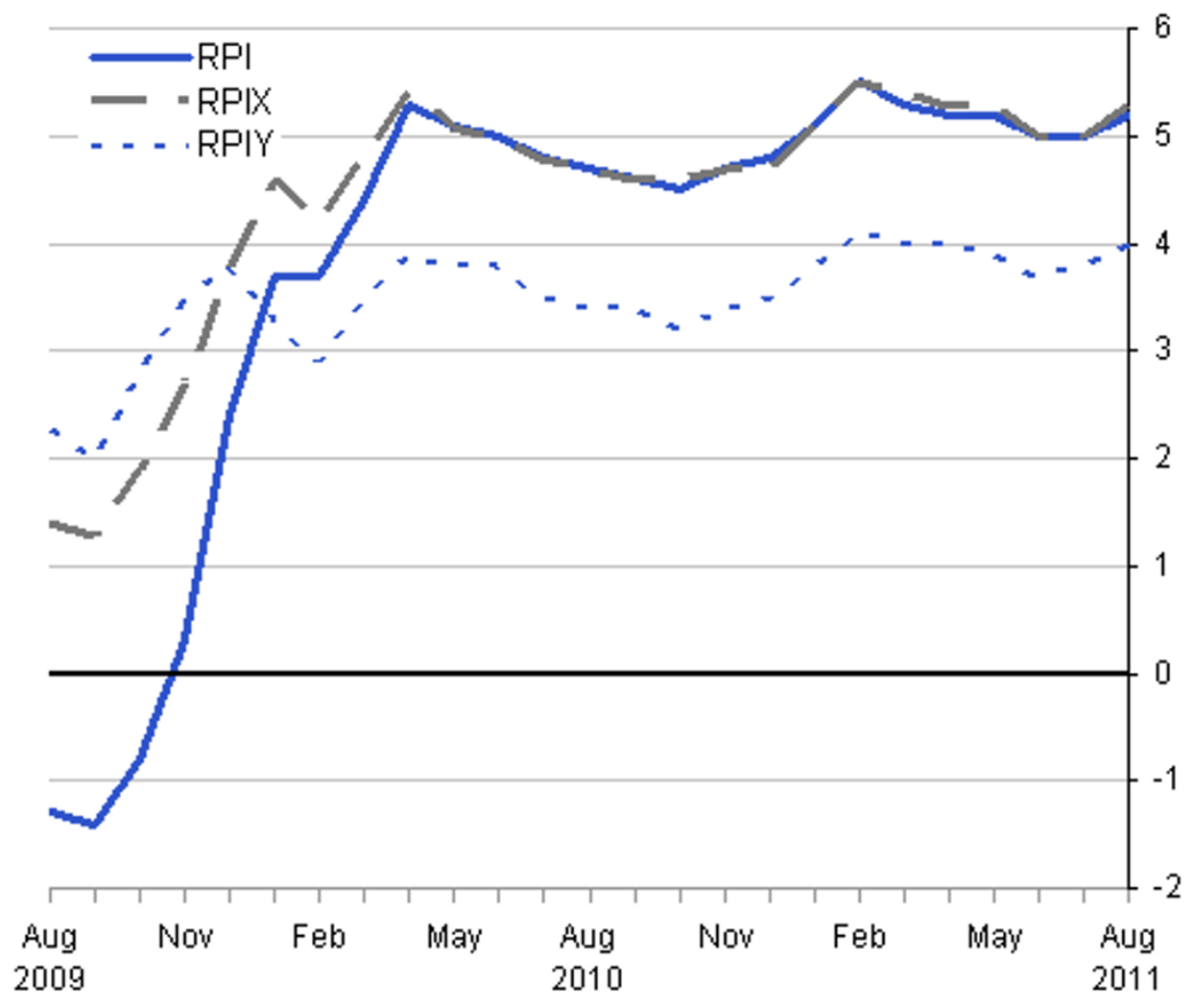




\section{Download chart}

XLS XLS format

$(24 \mathrm{~Kb})$

\section{All items Retail Prices Index excluding mortgage interest payments (RPIX)}

The RPIX is the same as the all items RPI except for mortgage interest payments, which is excluded from RPIX.

In the year to August, the RPIX rose by 5.3 per cent, up from 5.0 per cent in July. Therefore the RPIX 12-month rate rose by 0.3 percentage points between July and August compared with a rise of 0.2 percentage points in the RPI 12-month rate between the same two months.

Mortgage interest payments had a small downward effect on the change in the RPI 12-month rate between July and August. This and the impact of rounding are the reasons for the small difference in the change in the RPIX and RPI 12-month rates between those months.

\section{All items Retail Prices Index excluding mortgage interest payments and indirect taxes (RPIY)}

The RPIY is the same as the all items RPI except that it excludes price changes which are directly due to changes in indirect taxation (such as VAT) and mortgage interest payments.

In the year to August, the RPIY rose by 4.0 per cent, up from 3.8 per cent in July. Therefore the RPIY and RPI 12-month rates both increased by 0.2 percentage points between July and August. There were no changes to indirect taxation that impacted on the RPI between July and August and although mortgage interest payments had a small downward effect on the change in the RPI 12month rate, it was not sufficient to lead to a difference between the changes in the RPI and RPIY 12month rates between the two months. 


\section{Selected Records}

\section{Selected CPI Records}

\begin{tabular}{|c|c|}
\hline \multirow[t]{3}{*}{ All items CPI } & Annual rate $+4.5 \%$, up from $+4.4 \%$ last month \\
\hline & $\begin{array}{l}\text { Also }+4.5 \% \text { in May and April 2011, and October } \\
2008\end{array}$ \\
\hline & Last higher in September 2008 (+5.2\%) \\
\hline \multirow[t]{2}{*}{ Clothing \& footwear } & Annual rate $+4.0 \%$, up from $+3.1 \%$ last month \\
\hline & $\begin{array}{l}\text { Never higher since official series began in } \\
\text { January } 1997\end{array}$ \\
\hline \multirow[t]{2}{*}{ Housing \& household services } & Annual rate $+5.1 \%$, up from $+4.6 \%$ last month \\
\hline & Highest since July 2009 (+5.2\%) \\
\hline \multirow[t]{2}{*}{ Furniture, household equipment \& maintenance } & Annual rate $+5.8 \%$, up from $+4.8 \%$ last month \\
\hline & $\begin{array}{l}\text { Never higher since official series began in } \\
\text { January } 1997\end{array}$ \\
\hline \multirow[t]{2}{*}{ Recreation \& culture } & Annual rate $-0.8 \%$, down from $-0.2 \%$ last month \\
\hline & Lowest since December $2008(-1.2 \%)$ \\
\hline \multirow[t]{2}{*}{ Restaurants \& hotels } & Annual rate $+4.6 \%$, up from $+4.4 \%$ last month \\
\hline & $\begin{array}{l}\text { Never higher since official series began in } \\
\text { January } 1997\end{array}$ \\
\hline
\end{tabular}

\section{Download table}

\section{XLS XLS format}

$(23 \mathrm{~Kb})$ 


\section{Selected RPI Records}

All items RPI

All items RPI exc MIPS (RPIX)

Catering

Tobacco

Housing

Fuel \& light

Household goods

Clothing \& footwear

Leisure goods
Annual rate $+5.2 \%$, up from $+5.0 \%$ last month

Also $+5.2 \%$ in May and April 2011

Last higher in March 2011 (+5.3\%)

Annual rate $+5.3 \%$, up from $+5.0 \%$ last month

Also $+5.3 \%$ in May and April 2011

Last higher in March 2011 (+5.4\%)

Annual rate $+4.2 \%$, up from $+4.1 \%$ last month

Also $+4.2 \%$ in June 2011

Last higher in November 2008 (+4.4\%)

Annual rate $+12.3 \%$, up from $+12.0 \%$ last month

Highest since November 1999 (+13.1\%)

Annual rate $+1.4 \%$, down from $+1.5 \%$ last month

Lowest since February 2010 (+0.3\%)

Annual rate $+8.6 \%$, up from $+7.4 \%$ last month

Highest since June 2009 (+9.6\%)

Annual rate $+7.1 \%$, up from $+5.5 \%$ last month

Also $+7.1 \%$ in March 1981

Last higher in February 1981 (+8.4\%)

Annual rate $+13.2 \%$, up from $+12.2 \%$ last month

Also +13.2\% in May and April 1980

Last higher in September 1977 (+13.6\%)

Annual rate $-3.2 \%$, down from $-2.4 \%$ last month

Lowest since February 2009 (-3.6\%)

\section{Download table}

\section{XLS XLS format}

$(15 \mathrm{~Kb})$ 


\section{Background notes}

\section{New this month}

\section{Launch of the new ONS website}

1. The launch of the new ONS website on 27 August 2011 has brought changes to the design and format of statistical bulletins. The bulletin main body is available in html and pdf format with the detailed data tables available as Excel spreadsheets to help make it easier for users to manipulate the data. Time Series datasets continue to be made available in their current format. The new website improves the way users can access our statistics but many existing bookmarks and links no longer work and users need to update them.

2. The most efficient way to access the latest CPI and RPI data and briefing on the new website is via the key figures on the homepage: http://www.ons.gov.uk.

3. Further information on the $\mathrm{CPI}$ and RPI, including details of the methodology used to construct the indices, articles, historic data etc. is available at: http://www.ons.gov.uk/ons/ taxonomy/index.html?nscl=Consumer+Prices+Index.

\section{Further improvements to the services provided to users of consumer price indices}

4. The following improvements are being provided to users of consumer price indices with the publication of the August $2011 \mathrm{CPI}$ and RPI on 13 September:

- data available earlier and one stop shop for CPI and RPI data: the data previously published in the Focus on Consumer Price Indices publication is being made available to users a week earlier than previously, that is, at the same time as the CPI and RPI publication. In addition, all data published as part of the Consumer Price Indices Statistical Bulletin, in the Consumer Price Indices Briefing Tables are being published electronically via one Excel file at: http:// www.ons.gov.uk/ons/rel/cpi/consumer-price-indices/august-2011/index.html. This means, of course, that a separate Focus on Consumer Price Indices publication will no longer be required and therefore the July 2011 edition was the last one published

- publication of detailed CPI data: the individual price quote data and item indices that underpin the CPI are being published for the first time. Please note that the data that are published will be at a level which will mean that no individual retailer or service provider will be able to be identified. The data published this month cover January 1996 to March 2011. Going forward, these data will be updated once a quarter with around a three month lag compared with the latest CPI publication, for example, the data will next be updated when the November CPI is published on 13 December 2011, at which point the detailed data published will be extended to September 2011

\section{Next month}

5. Inflation for September 2010 to September 2011 will be published on 18 October 2011. CPI and RPI inflation rates between September 2010 and August 2011 were 4.5 per cent and 4.8 
per cent respectively. Inflation rates for September 2010 to September 2011 will take account of price changes between August 2011 and September 2011.

\section{Relevance}

6. The $\mathrm{CPI}$ is the main UK domestic measure of consumer price inflation for macroeconomic purposes. It forms the basis for the Government's target for inflation that the Bank of England's Monetary Policy Committee (MPC) is required to achieve. From April 2011 the CPI is also being used for the indexation of benefits, tax credits and public service pensions. The uprating is based on the 12-month change in the September CPI.

7. Internationally, the CPI is known as the Harmonised Index of Consumer Prices (HICP). HICPs are calculated in each Member State of the European Union, according to rules specified in a series of European regulations developed by Eurostat in conjunction with the EU Member States. HICPs are used to compare inflation rates across the European Union. Since January 1999, the HICP has also been used by the European Central Bank (ECB) as the measure of price stability across the euro area.

\section{Methodology}

10. The CPI and the RPI are compiled using the same underlying price data, based on a large and representative selection of around 650 individual goods and services for which price movements are measured in around 150 randomly selected areas throughout the UK. Around 180,000 separate price quotations are used every month to compile the indices. The outlets in which the prices are collected are selected randomly. Expenditure weights are held constant for one year at a time.

11. The selection of goods and services that are priced to compile the CPI and RPI is reviewed annually. The contents of the 2011 basket are described in an article published on the National Statistics website at:http://www.ons.gov.uk/ons/rel/cpi/cpi-rpi-basket/2011/index.html. The expenditure weights used to compile the indices are also updated each year. Additional details of the updated CPI and RPI weights for 2011 are available from the National Statistics website in an article published on 19 April 2011 entitled Consumer Prices Index and Retail Prices Index: Updating Weights for 2011: http://www.ons.gov.uk/ons/rel/cpi/cpi-and-rpi-index--updatingweights/updating-weights-2011/index.html.

12. Rates of change for the CPI are calculated from unrounded index levels, rather than from the published indices, which are rounded to one decimal place. The use of unrounded indices increases the accuracy of the calculation. The unrounded index levels are available on request. By contrast, rates of change for the RPI are calculated from the published rounded indices.

\section{Reliability}


13. Once the RPI indices are published they are never revised. CPI indices are revisable although the only time the CPI all items index has been revised was when the index was rereferenced to $2005=100$, which took place with the publication of the January 2006 indices.

\section{Comparability}

14. The CPI's coverage of goods and services was extended in stages in the areas of health, education, childcare and insurance, with effect from the January 2000, 2001, and 2002 indices. In 2000, there was also a change to the population basis for the weights which was broadened from private households to include expenditure by foreign visitors and residents of institutional households. Further details can be found in a series of articles: http://www.ons.gov.uk/ons/ guide-method/user-guidance/prices/cpi-and-rpi/index.html

15. The official CPI series starts in 1996 but estimates for earlier periods are available back to 1988. These estimates are broadly consistent with data from 1996 but should be treated with some caution.

16. RPI data are available back to 1947 but have been re-referenced on several occasions since then, generally accompanied by changes to the coverage and/or structure of the detailed sub-components. Details of these changes are given in Appendices 1 and 2 of the CPI Technical Manual: http://www.ons.gov.uk/ons/guide-method/user-guidance/prices/cpi-and-rpi/ consumer-price-indices-technical-manual---2010.pdf

\section{Other measures of inflation - main uses and methodological details}

17. Detailed explanations on the main uses and methodology used to construct the 'other measures of inflation' included within this statistical bulletin and how they differ from the CPI can be found in Chapter 10 of the CPI Technical Manual: http://www.ons.gov.uk/ons/guidemethod/user-guidance/prices/cpi-and-rpi/consumer-price-indices-technical-manual---2010.pdf. In summary:

- All items Retail Prices Index (RPI): the RPI is the most long-standing general purpose measure of inflation in the UK. Historically the uses of the RPI include the indexation of various prices and incomes and the uprating of pensions, state benefits and index-linked gilts, as well as the revalorisation of excise duties. Please note, though, that from April 2011 the CPI is being used to uprate benefits, tax credits and public service pensions.

The main differences between the CPI and RPI are:

- population base: CPI includes all UK private and institutional households and foreign visitors to the UK. The RPI includes private households only and excludes the highest income households and pensioner households mainly dependent on state benefits; these excluded private households account for around 13 per cent of all UK household expenditure 
- item coverage: the most significant difference is that the CPI excludes a number of items relating to housing costs (such as mortgage interest payments, house depreciation and council tax) that are included in the RPI

- index methodology - formula: the CPI mainly uses the geometric mean whereas the RPI uses the arithmetic mean to combine individual prices at the first stage of aggregation

- item coding: the CPI uses a standard international classification system whereas the RPI uses a system unique to itself and not used elsewhere. The different approaches reflect the fact that the $\mathrm{CPI}$ is used to compare inflation rates across Europe so a standard framework is required; the RPI is mainly used within the UK only

A breakdown of the differences between the CPI and RPI annual inflation rates can be found in the following link: http://www.ons.gov.uk/ons/guide-method/user-guidance/prices/cpi-and-rpi/ differences-between-the-rpi-and-cpi-measures-of-inflation.pdf

Also available here: http://www.ons.gov.uk/ons/guide-method/user-guidance/prices/cpi-andrpi/cpi-and-rpi--increased-impact-of-the-formula-effect-in-2010.pdf is an explanation on the increased impact that the different formula used to construct the CPI and RPI had on the indices during 2010.

- All items Retail Prices Index excluding mortgage interest payments (RPIX): this index is the same as the all items RPI but it excludes the mortgage interest payments component

- All items Retail Prices Index excluding mortgage interest payments and indirect taxes (RPIY): is an index designed to measure movements in 'core' prices as the index excludes price changes which are directly due to changes in indirect taxation (for example VAT; excise duties on tobacco, alcohol and petrol; local authority taxation; and vehicle excise duties) and mortgage interest payments. The purpose of the index is to obtain a better indication of inflationary pressures at times when prices are directly influenced by Government-driven changes

- Consumer Prices Index excluding indirect taxes (CPIY): is an index designed to measure movements in 'underlying prices' as it excludes price changes which are directly due to changes in indirect taxation (for example VAT, excise duties on tobacco, alcohol and petrol). As with the RPIY, its main purpose is to obtain a better indication of inflationary pressures at times when prices are directly influenced by Government-driven changes

- Consumer Prices Index at constant tax rates (CPI-CT): is an index where tax rates are kept constant at the rates as they were in the base period (currently January 2011). The analytical value of the CPI-CT is when it is compared with the $\mathrm{CPI}$; differences in the monthly and annual rates of change between the two indices provide an indication of the impact of tax changes on the CPI

\section{Accessibility}

18. This bulletin includes the August 2011 data, collected on 16 August 2011. Future publication dates are 18 October, 15 November, 13 December, 17 January, 14 February and 20 March. 
The European Commission (Eurostat) will release figures for the harmonised index of consumer prices (HICP) for the month of August 2011 for EU Member States, together with an EU average, on 15 September 2011. Further information on HICP for the European Union, Eurozone and other EU Member States is available from Eurostat's HICP web page: www.epp.eurostat.ec.europa.eu/portal/page/portal/hicp/introduction.

\section{Further information}

19. A more detailed quality report for this statistical bulletin is available at: http:// www.ons.gov.uk/ons/guide-method/method-quality/quality/quality-information/economicstatistics/index.html The report assesses the CPI and RPI against standard dimensions of quality such as relevance, accuracy and accessibility. The report was last updated in November 2009.

20. The mini Triennial Review of the CPI and RPI Central Collection of Prices is available at: http://www.ons.gov.uk/ons/guide-method/user-guidance/prices/cpi-and-rpi/mini-triennial-reviewof-the-consumer-prices-index-and-retail-prices-index.pdf

21. A full description of how the CPI and RPI are compiled is given in the Consumer Price Indices Technical Manual at: http://www.ons.gov.uk/ons/guide-method/user-guidance/prices/cpiand-rpi/consumer-price-indices-technical-manual---2010.pdf

\section{General}

22. Details of the policy governing the release of new data are available from the Media Relations Office. Also available is a list of the names of those given pre-publication access to the contents of this release.

23. In line with Consumer Price Indices Pre-Release arrangements, an advanced estimate of the CPI was provided to the Governor of the Bank of England and the Chancellor of the Exchequer $3 \frac{1}{2}$ working days ahead of publication. The Governor shared this information with the MPC, and officials present at the MPC policy meeting, on Thursday 7 September.

24. Follow ONS on Twitter at www.twitter.com/statisticsONS and Facebook at www.Facebook.com/statisticsONS

25. National Statistics are produced to high professional standards set out in the Code of Practice for Official Statistics. They undergo regular quality assurance reviews to ensure that they meet customer needs. They are produced free from any political interference.

26. This link provides a list of those roles and departments who received pre-release access to the August 2011 CPI Statistical Bulletin: Pre-release access list

(c) Crown Copyright 2011.

Next publication: 
18 October 2011

Media contact:

Tel: Luke Croydon 08456041858

Emergency on-call 07867906553

E-mail: media.relations@ons.gsi.gov.uk

Statistical contact:

Tel: Philip Gooding 01633455896

E-mail: philip.gooding@ons.gsi.gov.uk

Email: cpi@ons.gov.uk

$\mathrm{CPI} / \mathrm{RPI}$ recorded message:

Tel 01633456961

CPI/RPI Enquiries:

Tel 01633456900

\section{Issuing Body:}

Office for National Statistics

Media Contact Details:

Telephone: 08456041858

(8.30am-5:30pm Weekdays)

Emergency out of hours (limited service): 07867906553

Email:

media.relations@ons.gsi.gov.uk 